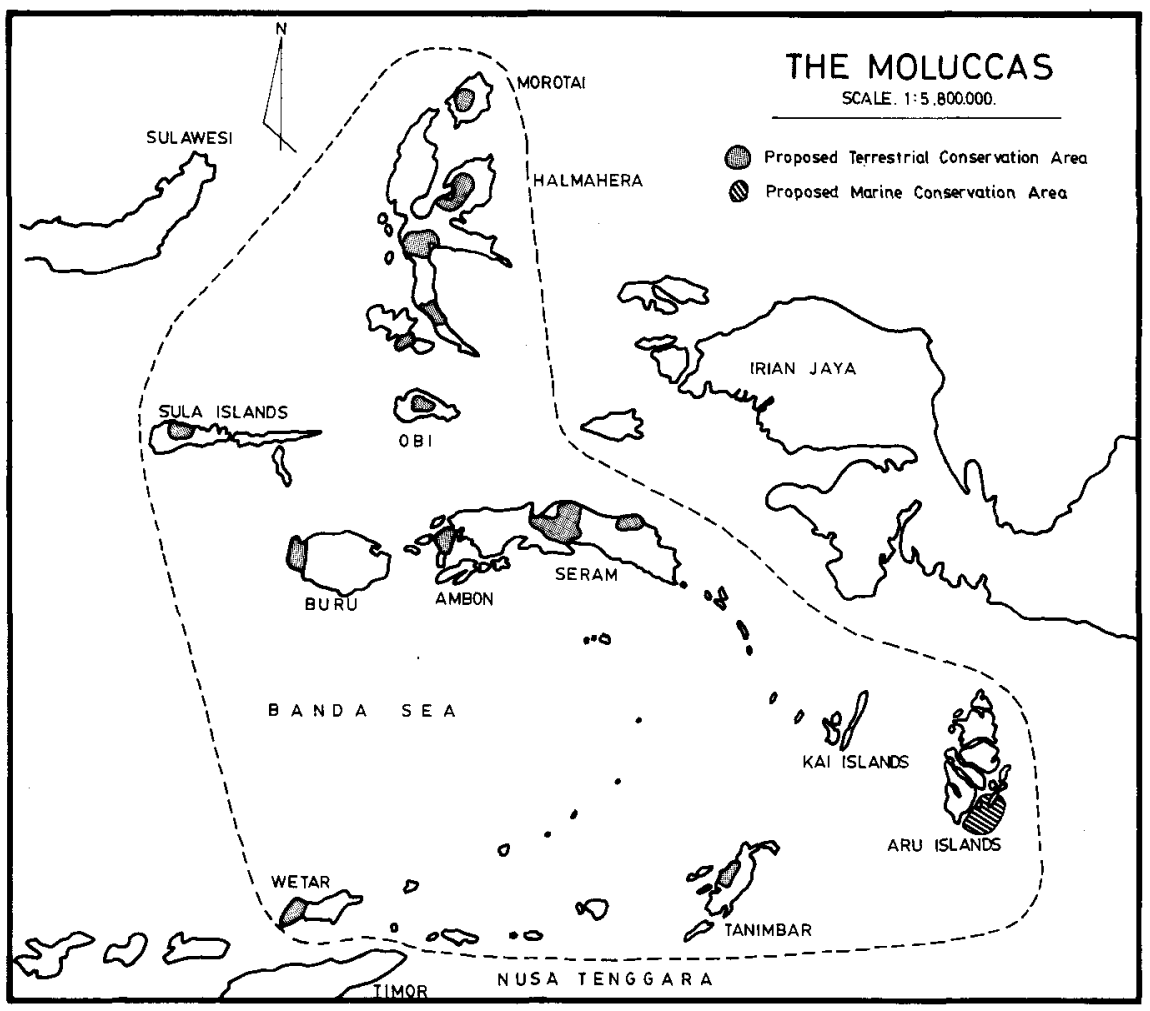

\title{
Threats to the Spice Islands
}

\section{Fred Smiet}

The wildlife of the widely scattered islands that comprise the East Indonesian province of Maluku, formerly the Moluccas, is unique and immensely important scientifically. More than a quarter of the birds are endemic species, as well as nearly a fifth of the mammals, several reptiles and land snails and at least 25 butterflies. Seventy per cent of the islands is still untouched. But large-scale commercial logging is making increasing inroads on the forest of the north and central islands, and commercial overfishing and siltation due to the logging are affecting the sea. The Indonesian Directorate of Nature Conservation, assisted by FAO, is drawing up a conservation programme, in which the author is involved, which includes recommendations for a 180,000 -ha national park on Seram Island and a 250,000-ha marine reserve in the Aru Islands.

The natural history of Maluku, or the Moluccas, is one of the least known in the world. Together with Sulawesi, formerly Celebes, and Nusa Tenggara, formerly the Lesser Sundas, this East-Indonesian province forms the biogeographic transition zone between Asian and Australian faunas, known as Wallacea, after Alfred Russel Wallace, the British naturalist who travelled extensively through these islands between 1856 and 1861; his book The Malay Archipelago is still the most 
lems in Maluku are mild compared with more densely populated areas in Indonesia. Only near large population centres, such as Ambon Island, does the population increase to as high as 200 people per sq $\mathrm{km}$, and here problems occur, such as the pollution of Ambon Bay, coral reef destruction and deforestation resulting in erosion.

In recent years a serious environmental threat has arisen in the form of largescale commercial logging operations. About 90 per cent of all forest in North and Central Maluku is under timber concession, and 17 companies are logging in 22 different locations. In 1980 the entire production of 1.4 million cubic metres of logs was exported. The Moluccan forests attract logging companies, because they contain several commercially valuable timber species including some dipterocarps, distances are short, and large ships can anchor close inshore. There is very little government control and the companies have a free rein, resulting in logging irrespective of steepness, soil fragility or altitude, and no reforestation all in defiance of government regulations.

Island ecosystems are in delicate balance and more vulnerable than mainland ecosystems. The Moluccan islands are geologically quite young, and steep slopes and high mountains occur on Halmahera, Seram, Buru, Sula and Obi. Topsoil is generally thin, and the often heavy rainfall, up to $4500 \mathrm{~mm}$ annually, combined with steepness, leads to severe erosion. There is no doubt that these fragile ecosystems will be seriously disturbed by this large-scale deforestation.

\section{Trade in Animal Products}

Trade in animals is a traditional enterprise in Maluku, and local people have always kept parrots and other pets. In recent years the export market has become lucrative, and large consignments of live animals are shipped daily through the harbours and airports of Ambon and Ternate. Part of this export trade is officially registered under the supervision of the Directorate of Nature Conservation (PPA) and in Ambon and Ternate law enforcement is quite effective. In the last four years, according to official PPA figures, 70,000 live birds, all species that are not officially protected, were exported from Maluku. Outside the main towns, however, law enforcement is difficult and it is impossible to check the many thousand kilometres of coastline, so the largest part of the export trade goes unregistered. Loads of animals are taken by boat to Ujung Pandang, Surabaya or Jakarta, while large fishing boats and log carriers sail straight to Singapore or Japan. Table 1 shows some data for animal products readily available on the Ambon market. Other species in trade include wallabies, mainly Thylogale bruijnii from the Aru Islands, and, increasingly, butterflies. The endemic butterflies of Seram are in great demand, and there are several 
Product

$\begin{array}{ll}\text { Red lory } & \text { Eos bornea } \\ \text { Chattering lory } & \text { Lorius garrulus } \\ \text { Salmon-crested } & \text { Cacatua moluccensis } \\ \text { cockatoo } & \\ \text { Palm cockatoo } & \text { Probosciger aterrimus } \\ \text { Great bird of } & \text { Paradiseae apoda } \\ \text { paradise } & \\ \text { Hawksbill turtle } & \text { Eretmochelys imbricata } \\ \text { Dugong } & \text { Dugong dugon }\end{array}$

Price/unit

US \$ Remarks

Ambon, Seram

5 Alive

North Maluku

16-24 Alive

Seram

32-40 Alive

Aru Islands

56-60 Alive

Aru Islands

80-100 Prepared skin

South Maluku 100-300 Carapace Aru Islands $8 / \mathrm{cm}$ Teeth

(for a pair of teeth with a length of $10 \mathrm{~cm}$ each: US\$160)

villages on Seram whose inhabitants depend totally on butterfly catching.

In general trade has not yet had a big impact on wild parrot populations. Most parrots, including cockatoos, have a great reproductive capacity, adapt readily to habitat alteration and profit greatly from the widespread introduction of fruit trees throughout Maluku. This, coupled with the fact that large stretches of original habitat still occur on most islands, has helped them to maintain stable populations despite the great hunting pressure, and colourful parrots and white cockatoos are still common in the forests of Seram and Halmahera and occasionally raid crops in nearby villages.

The future for Maluku's wildlife looks grim in view of the ever expanding logging activities and the accelerating trade and some of Maluku's species will undoubtedly become endangered in the near future if these factors are not controlled.

\section{Marine Environment}

Maluku is known as the province of 999 islands; only 10 per cent is land, and the total coast length is at least $10,000 \mathrm{~km}$. Thus the marine environment is dominant both geographically, and economically; many people depend on marine products for food or trade.

Table 2 Proposed Forest Conservation Areas on the Major Islands of Maluku Province

\begin{tabular}{|c|c|c|c|}
\hline Island & $\begin{array}{c}\text { Size } \\
\text { sq km }\end{array}$ & $\begin{array}{l}\text { Proposed Reserve size } \\
\text { sq km }\end{array}$ & $\begin{array}{l}\text { Altitudinal range } \\
\mathrm{m}\end{array}$ \\
\hline Morotai & 1800 & 450 & $0-1250$ \\
\hline \multirow{3}{*}{ Halmahera } & 18000 & 850 & $200-1500$ \\
\hline & & 600 & $0-1400$ \\
\hline & & 500 & $0-1350$ \\
\hline Bacan & 5700 & 150 & $0-2200$ \\
\hline Obi & 3780 & 150 & $500-1750$ \\
\hline Sula Islands & 6000 & 150 & $500-1800$ \\
\hline \multirow[t]{3}{*}{ Seram } & 18625 & 1300 & $50-1100$ \\
\hline & & 21800 & $0-3027$ \\
\hline & & $3 \quad 300$ & $0-500$ \\
\hline Buru & 9000 & 400 & $0-2800$ \\
\hline Wetar & 3624 & 250 & $0-1500$ \\
\hline Tanimbar & 5085 & 200 & $0-200$ \\
\hline Aru Islands & 6325 & 800 & $0-70$ \\
\hline
\end{tabular}


Some of the consignment of 500 cockatoos confiscated in Ambon harbour

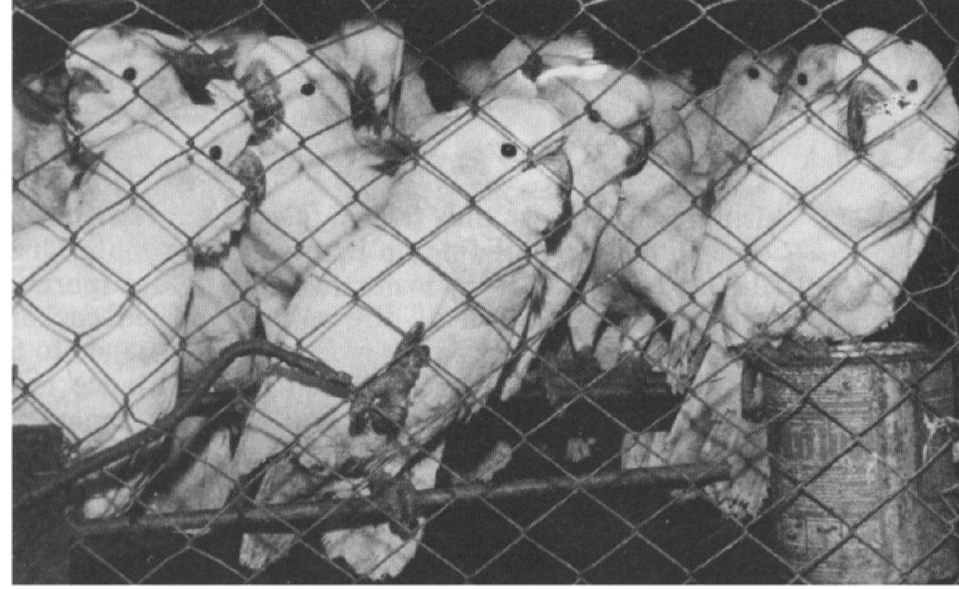

Oceanic currents and upwelling zones make the Banda Sea very rich in fish. The fringing reefs, reef flats, mangroves, sea grass beds and mudflats, together with gradients in salinity and turbidity, give a variety of ecosystems, which make this one of the world's richest marine environments, and one that, until recently was relatively untouched by human influence. Now large-scale problems have arisen in the form of overfishing by commercial companies and siltation from soil erosion due to the extensive logging. The situation calls for urgent protection for the coastal ecosystems, and surveys to select areas for protection. One area has been surveyed and a proposal drawn up for the 250,000-ha Aru Tenggara Marine Reserve. This part of the Aru Islands comprising a variety of ecosystems mangroves, reefs and sea grass beds - contains seven endangered species listed in the IUCN Red Data book: four marine turtles - green Chelonia mydas, hawksbill Eretmochelys imbricata, both known to nest, loggerhead Caretta caretta, and Pacific ridley Lepidochelys olivacea; two crocodiles, the saltwater Crocodylus porosus and $C$. novaeguineae, and dugong Dugong dugon. All are also locally endangered, since local people hunt them to trade their products. Turtle eggs are collected and carapaces sold, crocodiles are traded alive (juveniles) or dead (skins), and dugong are hunted for meat and teeth: the price for dugong is so high that they are often hunted specially for the teeth, which are fashioned into cigarette holders and other trinkets.

\section{Conservation Activities}

The riches and unique qualities of Maluku warrant the establishment of conservation areas throughout the province and on all the major islands. During my one-and-a-half year stay in the islands as an FAO Associate Expert we have selected and plotted a system of 14 terrestrial conservation areas on all the major islands, indicated on the map and in Table 2, a total of 690,000ha. They were selected on the basis of aerial photos and field work, and include areas important for water catchment and the fragility of their top soil. This system of reserves is now being processed by the provincial and national governments. Undoubtedly there will be modifications, but their establishment in one form or another will be a major conservation achievement. in Maluku. Feasibility studies and a management plan have been completed for the most important of these areas, the proposed 180,000-ha Manusela National Park in Central Seram, originally proposed in 1978, which comprises all Seram's forest ecosystems from sea level to the top of Gunung Pinaia, at $3027 \mathrm{~m}$ the highest peak in Maluku. All Seram's 14 endemic bird species are recorded from this area, and also five endemic mammals described at the beginning of this century and collected here, and 
which are still known only from a few museum specimens collected 70 years ago!

The PPA, now building up its branch in Ambon, has focused on the animal trade, and exports from major harbours and airports are now under control. The recent confiscation of 500 sulphur-crested cockatoos Cacatua galerita in Ambon harbour on their way from the Aru Islands to Singapore, was a remarkable success. Maluku will need technical assistance in the near future for the establishment and development of both the Manusela National Park and the Aru Tenggara Marine Reserve. WWF has taken on both projects as part of its second five-year Indonesia programme, and may include a third Maluku project on the status of parrot and cockatoo populations threatened by logging operations and the ever increasing animal trade.

At present Maluku is about 70 per cent untouched by human influence and immensely valuable for conservation. A start has been made to preserve it, but the logging threat is most serious and conservation still has a long way to go.

Fred Smiet, c/o Project Kali Konto, Jalan Tugu 3, Malang, Indonesia.

\section{New Primate Records for Rwanda}

The existence of two primate species previously unrecorded in Rwanda has been confirmed in the Nyungwe forest by a Swiss zoologist Michael Storz. These new records of the grey-cheeked mangabey Cercocebus albigena and the mona monkey Cercopithecus mona, together with a single group of redtails C.lascanius; in an isolated forest patch (also a first record for Nyungwe), bring the total of diurnal primates in this forest to seven, including the chimpanzee Pan troglodytes. Both mangabey and mona occur in the lower parts of the forest (up to $2100 \mathrm{~m}$ ), the former being abundant and the latter rare. Storz has also regularly observed aggregations of up to 150 black and white colobus Colobus angolensis, by far the largest group size ever recorded.

Nyungwe forest is one of the largest rainforest relicts of eastern Africa (c. $950 \mathrm{sq} \mathrm{km}$ ) and is unique in that it covers the altitudinal range $1600-2700 \mathrm{~m}$. It is a vital water catchment area for a large part of Rwanda, the most densely populated country in Africa, but widespread agricultural encroachment and illegal logging, together with the destructive activities of approximately 3000 gold miners, are threatening its survival. Primates are not hunted, hut all other large mammal species have been virtually eliminated. Buffalo háve probably gone and only a handful of elephants survive. Moreover Nyungwe is the only known refuge of the black duiker subspecies Cephalophus weynsi lestradei.

\section{Problems in PNG}

Papua New Guinea has been regarded as one of the copybook examples of a Third World country with progressive wildlife conservation policies, but the 1982 budget proposals threaten to forfeit this reputation. The entire Wildlife Division has been reduced to one project with 13 staff; the Marine Turtle Project has been discontinued, along with the projects for dugong, deer, publicity, education, licensing, and law enforcement, and the provincial projects. PNG may in future find it difficult to carry out its CITES responsibilities. Conservationists are rallying round, but as $O r y x$ goes to press we have no information as to their success. 